\title{
Inadaptation to Poro and Emergence of the Marginal District of "Mongaha" in Korhogo (Northen Côte D'ivoire)
}

\author{
Arsène KADJO \\ Université Peleforo GON COULIBALY de Korhogo \\ Korhogo, Côte d'Ivoire
}

\begin{abstract}
A traditional initiatory institution in the Senoufo country, "Poro" participates in the training of members of society and in the internal cohesion of the group. However, due to certain social contingencies, we meet social actors who do not adapt to them. This paper therefore proposes to analyse the correlation between this maladjustment and the emergence of a marginal neighbourhood, "Mongaha". The study revealed that "Poro" is a rite of passage in the Senoufo social order through three strata and aims at enculturation with a view to the social integration of the individual. As a result, any refusal to adapt is liable to social exclusion. The point of completion of this social exclusion is the creation of the village of "Mongaha" which enshrines a spatial exclusion.
\end{abstract}

Key words: Initiation, marginalization, inadaptation, Mongaha, Korhogo

\section{Résume}

Institution traditionnelle initiatique en pays sénoufo, le «Poro » participe à la formation de des membres de la société et à la cohésion interne du groupe. Seulement, fort de certaines contingences sociales, l'on rencontre des acteurs sociaux qui ne s'y adaptent pas. La présente s'est donc proposer d'analyser la corrélation entre cette inadaptation et l'émergence d'un quartier marginal ; celui de «Mongaha ». L'étude a révélé en effet que le « Poro » constitue un rite de passage dans l'ordre social sénoufo à travers trois strates et vise l'enculturation en vue de l'intégration sociale de l'individu. De ce fait, tout refus d'adaptation est passible d'exclusion sociale. Le point d'achèvement de cette exclusion sociale est la création du village de «Mongaha » qui consacre une exclusion spatiale.

Mots clés : Initiation, marginalisation, inadaptation, Mongaha, Korhogo

\section{Introduction}

The Senoufo society is initiatory. Initiation is done through "Poro", a cultural institution of socio-economic, sociopolitical and educational scope. The traditional education promoted there is collective, functional, pragmatic, oral, continuous, mystical, multi-purpose and integrationist (A. PARE-KABORE, 2013, p.8). This institution governs all social, religious and political activities. It therefore fulfils several functions within Senoufo society and contributes fundamentally to the socialization of the actors. Initiation to Poro is therefore a necessity that is both indelible and unavoidable for them. Thus any individual who has to live in this society must submit to it (N. HOLAS, 1956). Failure to submit to it, or else not to be initiated into Poro among the Senoufo people is liable to exclusion and synonymous with marginality. The concept of marginality does not refer here to a distancing from the social in the sense of a more or less complete deterioration of living conditions. This reading polarizes trends around elements such as precariousness, vulnerability, "ghettoisation", isolation (S.V. MONTAGNE, 2007, p.6). For authors such as (ASCHER, 1995; N. MATHIEU and F. SAINT GIROUX, 2004, H. BALAN, 2017) it takes on a dual dimension, namely the marginality desired and the marginality suffered. The first is the result of a voluntary exclusion from the cultural imperatives of a given community by certain social actors. The second stems from economic contingencies imposed on actors without them having any means of recourse. These forms of marginality are rooted in the analysis of poverty. Marginality is therefore perceived as the result of social inequalities.

Another facet of marginality is the inadequacy of individuals to a culture, particularly in the context of migration (D. CUSH, 2009, p.6) and would apply to 'an individual who lives on the margin of two cultures and two societies whose interpenetration and fusion have never been fully realised' and who would be unable to identify fully with either of the two cultures in which he or she participates. This reading, although highlighting the link between the stakes of culture and marginality, does not reveal the aspects of social and geographical marginality which are in line with the purpose of this study.

Indeed, the Senoufo society, on the strength of its beliefs and the functions of "Poro", places the rite of initiation into "Poro" as a rite of passage in the sense of (P. BOURDIEU, 1982). It thus makes it possible to separate those who have undergone it from those who have not yet undergone it, as well as those who will not undergo it in any 
way, and thus to institute a lasting difference between those who are concerned by this rite and those who are not, precisely because they refuse to submit to it. All things that translate their maladjustment to "Poro".

From this point of view, the category that interests this study falls under the heading of social marginality. Social marginality takes on its full meaning in the definition given by the Larousse dictionary, which understands it as the inability or refusal of certain individuals or groups to integrate or submit to the dominant social norms (R. CASTEL, 1994). This deviation from the norm, whether suffered or chosen, can produce specific places. This is the case, for example, for the socially marginalized in the history of Senoufo people, who, in addition to not participating in community life, are not allowed to cohabit with the initiated, hence the emergence of the district of Mongaha. How then did the maladjustment to "Poro" contribute to the emergence of the marginal district of"Mongaha" in Korhogo in the north of Côte d'Ivoire?

The aim of this article is therefore to analyse the correlation between maladjustment to 'Poro' and the emergence of the marginal district of 'Mongaha' in Korhogo.

\section{Materials and methods}

\subsection{Materials}

\subsubsection{The area of study}

The geographical scope of this study is the district of " Mongaha". It is located at the extreme north of Korhogo on the Korhogo-Boundiali axis. This social space borders several districts of Korhogo. To the north it is bordered by Sonzoribougou, to the east by the district of Koko, and to the south by the road of Kapélé. The map below shows the study site:

\section{Figure 1: Presentation of the area of study}

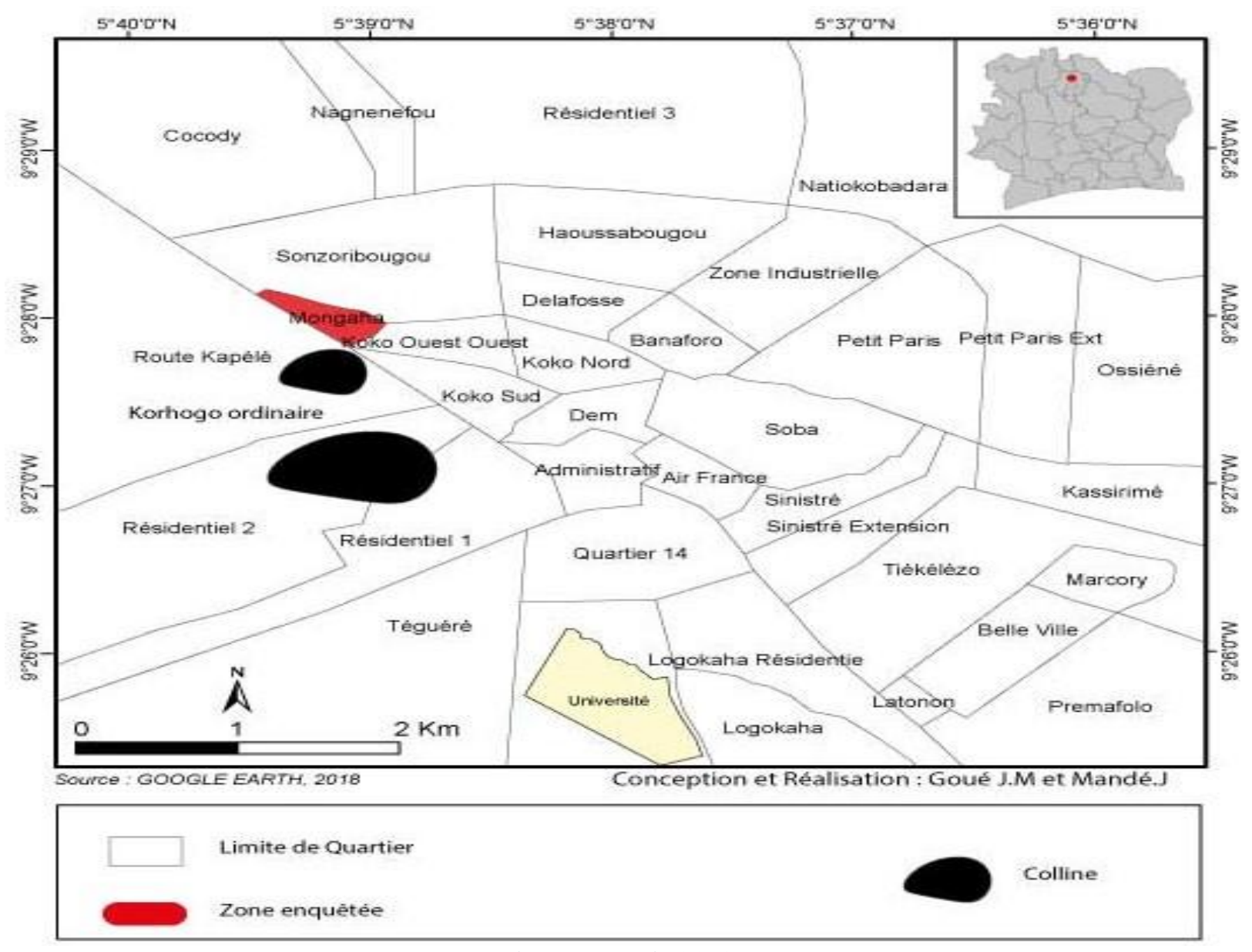

Source : INS, 2019

\subsection{Techniques of Survey}

The data collection, which took place from June to August 2020, involved both directive and semi-directive interviews. The interview guides used as tools were sent to the cantonal chiefdom of Korhogo, to the three main sacred wood chiefs, notably the one in the Koko district (district of the founders of Korhogo), the one in Sinistré and the one in Soba. These three districts contain the first "Sacred Woods" of the Senoufo society. From them all 
the others have emerged. In addition to these people, the head of the district of Mongaha and three initiates with the main roles (military, political and economic) were interviewed.

A few administrative officials, including the mayor and the delegated representative of the highmediation, himself an initiate and son of Korhogo, were interviewed. These interviews focused on the fundamental principles of Poro, their impact on the governance of Senoufo society, the sanctions linked to the failure of social actors to adapt to Poro and its effects. In addition to these actors, the interviews targeted ten (10) members of the district of Mongaha. These are descendants of the original inhabitants of the district. They are of the third generation of inhabitants. With them, it was possible to discuss the history of the district in order to understand the issues involved in its creation. A total of 19 people were interviewed as part of the study.

\subsection{Data Treatment and Analysis}

The data collected was manually processed due to the small size of the interviews. The various interviews were transcribed in order to analyze the content of the discourse and to identify the nodes of meaning in relation to the research objectives. The theoretical anchoring of the study was based on the socio-anthropological explanation of the phenomenon studied, using socio-historical and ethnographic approaches. The socio-historical analysis (G. NOIREL, 2008) makes it possible to highlight the cultural configuration of the Senoufo society as well as the values on which its existence is based. The social history of the Senoufo society depicts the foundations of its experience at the cultural, economic, religious and political levels. Thus, as indicated (G. NOIREL, op.cit), reflection on the history of this people favours the study of practices that link a certain number of actors within the same configuration. This configuration is the social order in force in the study society. It highlights the basic principles of relations between members of the Senoufo society based on the referents inscribed in "Poro". Every member of the Senoufo society is linked to the other members by his or her initiation to the different rites of "Poro". It is only through this initiation that the Senoufo individual acquires the state of maturity that makes him a member of society and a stakeholder in all social praxis.

Reading this scheme for clarifying Senoufo social status requires a description not only of the attributes of "Poro" but also of the process by which the marginalization of Senoufo individuals who evade initiation into "Poro" takes place, hence the ethnographic approach.

\section{Results}

\section{1 "Poro" as a rite of passage in the Senoufo social order}

The cultural monograph of the Senoufo people is exclusively related to the initiation to poro. This cultural trait is at the heart of the existence of this people. Initiation to poro can also be defined as a cultural principle established with the aim of forming a group of Senoufo individuals to the physical and metaphysical knowledge that governs society. It is a code that every Senoufo actor must decipher or decode in order to have access to this society. To this end, it constitutes the essential link in the functioning of this people. In this section, we will look at the three main layers of initiation and the different functions performed by "Poro" in the Senoufo society.

\subsubsection{The different levels of initiation to "Poro".}

The initiation to "Poro" follows an order, as attested by the chief of the "Sacred Wood" of the district at the origin of the foundation of the town of Korhogo:

"Three main strata structure the initiation to "Poro" among the Senoufo of Korhogo. They are Poworo, Kwonro and Tyolog. These three main strata or stages respond to an initiation cycle that extends over 21 years, 7 years of which are spent in stages. Each of these stages is therefore subdivided into steps each corresponding to a mythological idea. "K.Z, Chief of the Sacred Wood of Koko

In addition to this respondent's explanations, a training specialist, who is both a teacher and the head of a sacred grove, provides a justification of these three strata:

"These phases and levels have each an equivalence in French education, i.e. primary education, which includes preschool, primary and higher education. This correspondence therefore starts from pre-school to $\mathrm{cm} 2$, which gives us at least 7 years of training. The second phase is from the 6th grade to the final year of secondary school, which is equivalent to a second phase of training, and finally from the first year of university study to the doctorate, which is equivalent to a further 7 years of study. In these phases, each year is equivalent to a specific training, however, for your study, the three main phases and their meaning would suffice. "K.D., CAFOP Professor and Chief of the "Sacred Wood"

This approximation to the known academic training system indicates the formative and educational value in force in "Poro". The three strata of initiation are the "Poworo". This is the preliminary phase. It concerns children from 6 
to 10 years old. They are trained to learn how to handle the little daba or "kamag" and become familiar with the symbols.

The second phase is the "Kwonro" phase, also known as the fun phase, which is aimed at young people between the ages of 10 and 30. During this stage, the initiate is taught the practice of community life.

All the instruction is centred on what the sociologist would call enculturation, that is to say, the integration of the individual into the community for the good of which he will henceforth have to bear with the abrogation of his own sacrifices. The interviewee below attests to this:

"This second stage is where young people are taught to put themselves at the service of the community. They acquire the cultural, physical and metaphysical rudiments of Senoufo society. They become aware of their role and their cultural identity" C.S., Initiate and Delegate Mediator of the regionof Poro.

Finally, the third stratum is that of the "Tyolog" built in 12 steps forming "Poro", addressed to adults between 30 and 35 years of age. This last initiatory cycle can be done without the two previous phases and is obligatory. Initiation is based on the total integration of the individual into the group, a clear visibility of all social duties as the following respondent points out:

"It is at this stage that the masters designated from among the former initiates really come into action. These former initiates, these masters must gradually, over a period of seven (7) years, provide very extensive theoretical and practical instruction on religion, magic, totemic and historical traditions, customary laws, and the attitude to be observed towards the different members of the community, old men, mature men, elders and women. This apprenticeship is still technical since it includes everything that is important to know about gathering, farming, hunting, fishing, making gear and traps". Y.A, chief of a "Sacred Wood"

In the analysis of the different strata of initiation to "Poro", the educational dimension, both material and spiritual, and the formative dimension that they contain participate in the constitution of the being.

This is true of "Poro", which establishes the limits of the social order to be preserved. This is reflected in our social perception of it.

"The very objective of the initiation to "Poro" is to open access to our society. As such, it fulfils several functions", C.I, Chief Canton of Korhogo.

\subsubsection{Social perception of "Poro" in the Senoufo country}

This perception is based on the values of training and the perpetuation of community social ties. "Poro", because of its importance without the Senoufo society, is subject to various perceptions depending on the field of expression of the key social actors. The respondent below describes how "Poro" is read.

"Poro" is an institution of social reproduction. It strives to remain as faithful as possible to reproduce the oldest practices and allow for the continuity of the established order" C.K., Secretary of the Chief Canton of Korhogo.

This respondent's reading is in fact based on the system of succession of the different classes, one after the other during the three strata of initiation to "Poro". Without exception, each of these classes faces a certain number of tests; secrets are confided to each of the members who therefore put them at the service of the group, all of which contribute to the consolidation of the group's unity, as this interviewee attests:

"It's true that our society is highly hierarchical. Just like brotherhood of age and age groups, it is profoundly egalitarian insofar as during their training, the tyolo when they join the family of their respective masters are confronted with the same realities (treatment) without distinction". T.B., Head of military training of the Tyolo, "Sacred Wood" of Koko

This egalitarian treatment of the "Tyolo" by integrating the family of their masters aims at consolidating the links between the members of each age group. For several years they are subjected to the same trials, so they end up weaving together, beyond the bounds of friendship, fraternal relations and solidarity which are sometimes even above family ties. He goes on to say:

"Initiation to poro is the key that facilitates access to our society". "T.B., Head of military training of the Tyolo, "Sacred Wood" of Koko.

"Poro" thus appears to be the institution for the integration of the Senoufo into its community. Failure to conform or adapt to it is a cause of marginalization.

\subsection{From the inadaptation to "Poro" to the emergence of the marginal district of "Mongaha".}

The inadaptation to "Poro" can be summed up in the refusal of some members of the Senoufo community to go through the initiation rites to "Poro". This refusal leads to the social marginalization of the resistant individual. 


\subsubsection{Inadaptation to "Poro" and "Monhon" or marginal status}

In the Senoufo society, the historical factor of the maladjustment to"Poro" remains historically the adoption of the Muslim religion by a section of the population. Initiation was seen through the prism of belief as idolatry. The comments of the respondent below attest to this:

"Traditionally, the Senoufo people have their beliefs. They are said to be animist, which is a Western appreciation of ancestral African practices. One of the elements, not to say the basis of these beliefs is 'Poro'. Under this view, the people who, in the first moments of the appearance of Islam in the Senoufo land of Korhogo, embraced this new religion refused, in the light of the doctrine of abandoning all rituals in favor of devotion to Allah, to be initiated, if not to follow the initiation rituals to "Poro". Some of them, for other reasons of their own convenience, refused to be initiated" I.C., teacher of CAFOP, initiated, living in Koko.

Thus, in the name of faith in Allah and for other reasons, many Senoufo are opposed to their fellow Senoufo by refusing initiation to "Poro". This refusal exposes them to exclusion from Senoufo social life as mentioned below:

"Any Senoufo individual who is not initiated is not one in the social and cultural imagination of the Senoufo people. To tell the truth, he is not even considered as a man and therefore cannot participate in the life of society. Society does not confer any value on this individual. He does not have the status of a man. He is a "Monhon", it is now his status and this relegates him to the rank of the marginalized" Y.S., chief of the sacred forest of Soba and dean of the chiefs of the "Sacred Wood" of Korhogo.

"Monhon" or "monbélé" which literally means "layman" in the Senoufo language. It is in fact a mockery to stigmatize the uninitiated at "Poro" and to indicate their inferior position in the Senoufo social arena. This term is used to indicate that they do not have the right to display themselves in the midst of their peers.

"The very presence of a "Monhon" or "Mondélé" is a disgrace to his family. No Senoufo family will agree to give their daughter to him in marriage and he has no right to speak in the assembly, let alone have responsibilities of any kind. His mere presence is even an affront. He is therefore obliged to stay away even from funeral ceremonies and family problems. If, in a Senoufo family, the elder has not done Poro and the younger has done the initiation, the younger becomes the elder for his family. The non-initiated is excluded from any social participation" S.K., initiated and notable of the chief canton.

These remarks reflect a very rigid socio-cultural context that is almost intolerant of the uninitiated. Their status is linked to their maladjustment to "Poro", which excludes them from society and makes them a social outcast. This shouting malaise will even lead to the creation of a neighbourhood for the uninitiated in order to establish a definitive break with Senoufo society. Thus, we move from social marginality to spatial marginality.

\subsubsection{From social marginality to spatial marginality through the creation of "Mongaha".}

The oral tradition on the creation of Mongaha indicates the history of its foundation. Only the information gathered from the cantonal chieftaincy gives the following information:

"Mongaha was founded by Sandonan and Gbérinan. Both belonged to the caste of blacksmiths. Sandonan was the uninitiated nephew of the Poro de Gbérinan (the uncle who initiated him). To put an end to his nephew's life of frustration and marginalization, the uncle decided to settle his nephew in a territory far from the Senoufo society from which he was daily humiliated and reminded of his condition as "Monhon". C.K., Secretary of the Chief Canton

The Senoufo people have a matrilineal inheritance system. The maternal uncle is in charge of his nephews. For this reason, Gbérinan has decided for the well-being of his nephew to keep him away from society. After the uncle's death, Sandonan settled permanently in this new social space as the informant below indicates:.

"It is after the death of his uncle that Sandonan will definitively record his refusal of social participation by settling permanently outside the Senoufo geographical space and constitute his own space" C.K., Secretary of the Chief Canton.

Insiders used the term "monbéle" to refer to this place. In the local Senoufo language, "monbélé" refers to the deviants of the Senoufo society or the person not initiated to "Poro".

This label, which borders on social stigmatization, is used to mark the difference between this space of the uninitiated and that of the initiated. Moreover, in any society in general and in Senoufo society in particular, the name of a village or space is taken from the name of its first occupant. One could therefore call this place Sandonakaha or Sandonagaha (village of Sandona), but the space is called "Mongaha". Etymologically, Mongaha is composed of two variants: Monhon or monbélé which means uninitiated and Gaha which is similar to kaha (which means village in the local Senoufo language).

In the case of Mongaha, this name was given by the Korhogo insiders in order to show the rest of the Senoufo society that this social space is different from their own. 
Mongaha is the village or the space considered to be that of the non-eligible members of Senoufo society or the space of the non-initiated. It presents itself as a refuge for actors in Senoufo society who have not done and do not accept initiation to "Poro". This space was designed to meet a need for social freedom. Mongaha thus appears to be the place that allows the uninitiated to move around and to be protected from the social sanctions imposed on offenders in the Senoufo society regulated by the initiation to "Poro".

The creation of this new social space is the result of the exclusion or marginalization experienced by some noninitiated individuals in the Senoufo society. The social existence of the non-initiated in this context borders on stigmatization in the sense that this individual is deprived of any social faculty to act within this group. This attitude leads this individual to exclude himself from his society of origin.

\section{Discussion}

The results reveal socio-cultural factors as key factors that contributed to the erection of Mongaha. The cultural fact in Senoufo society is marked by the predominance of initiation to poro through the different strata of initiation. These are in fact rather than step-by-step rites, rites of consecration, or rites of legitimation or, quite simply, institution rites (giving this word the active meaning it has, for example, in the expression "institution of an heir", because it is a question of bequeathing know-how, know-how to be and knowledge to the younger generation. To speak of a rite of institution is to indicate that any rite tends to consecrate or legitimize, that is to say, to cause an arbitrary limit to be disregarded as arbitrary and recognized as legitimate, natural; or, which amounts to the same thing, to operate solemnly, that is to say, in a lawful and extra-ordinary manner, a transgression of the constituent limits of the social and mental order which it is a question of safeguarding at all costs (P. BOURDIEU, 1982, p. 61).

We see in passing that, since the institution consists in assigning properties of a social nature which are destined to appear as properties of a natural nature, the institution rite logically tends to integrate the properly social oppositions, such as initiated/non-initiated, into series of cosmological oppositions, which represents a very effective way of naturalizing them. Thus, initiation rites consecrate the difference between social actors: they constitute, as a legitimate distinction in terms of values, Senoufo social norms enshrined in "Poro". The separation accomplished in the ritual (which itself operates a separation) has a consecrating effect for those of the initiated actors and the relegation outside the Senoufo social system of the non-initiated as well as those who would never know it, in this case the immigrants. Such is the case with "Poro" (R. ROCHEFORT, 1986).

Having said that, it was therefore a determining factor in the creation of this social space. Indeed, in any society, culture occupies an important place. Rules and principles are influenced by it. The individual living in this society must therefore submit to its requirements. Otherwise, the nonconformist must expect sanctions that can go as far as exclusion (L. RIOUX).

As for Sandona, who is at the origin of the creation of Mongaha, wanting to escape negative sanctions because of his maladjustment to "Poro", he has excluded himself from his society of origin. This self-exclusion is the result of the marginalization he endured.

The founder of Mongaha was forced to leave his family for a destination that would allow him to live without suffering the horrors of not respecting the norms of his society. This situation of marginality makes it impossible for the marginal man to fully identify with the culture in which he should participate (D. CUSH, 2009). He is an individual "whom fate has condemned to live in a society and culture that is antagonistic to him, and "who retains discord in his soul" (PARK, 1928, p 21).

Following Sondona, several like-minded individuals decided to join him to live permanently in Mongaha. This social situation shows the cleavage that is often perceived between the psychology of the individual and the psychology of society. It can be deduced from this that the social norms enacted by a society are not always in line with individual aspirations (G. MAUGET, 2008). These norms do not always take into account the social changes that might occur. The coercive nature obscures the social dynamics to which individuals may be subject. What therefore poses a problem is the perpetual aspect of these rules. So, not wanting to live under the injunction of these rules, some individuals like Sandona preferred to find refuge in another social space, hence the creation of Mongaha.

In this respect (GOFFMAN, 1975), is part of an approach that tends to consider exclusively the personality of the individual in society. It thus shows that in any society, every individual is endowed with a social identity. It is defined as everything that is specific to the individual (his personality, desires and ambitions). When this identity is not taken into account in a relationship, it can create a stigma in the individual who will be forced to withdraw.

Goffman's Weberian approach emphasizes the importance and consideration that society must have for the individual's social identity. There is therefore a breakdown of the link when the social identity of the individual and society are at opposite ends of the spectrum. We must therefore not overlook the fact that there is usually a relationship of domination between society and the individual. 
Goffman's approach is certainly interesting but does not take into account all the social realities. If society were to bend to the demands of each individual's social identity, social anarchy, and an unprecedented disorder would be evident in it and would undermine the very foundations of society and even lead to its demise. The individual could not therefore be ex-nihilo the group that is part of a cycle of social reproduction and perpetuation.

\section{Conclusion}

In conclusion, Senoufo society is strongly marked by its attachment to "Poro", a rite of passage of the individual from childhood to adulthood, which is the culmination of a long learning process. In order to live in this society, one must fundamentally go through the fire of this initiation. Otherwise, the individual is punished. It is this social punishment that has favored the creation of Mongaha. Socio-cultural factors led to the establishment of this space as a living environment. To this end, it represents the space of the marginalized or non-eligible members of Senoufo society. Moreover, Mongaha is a mockery name attributed by Korhogo insiders. This is to mark the fundamental difference between the social space of the Senoufo people, animated by the initiation to poro and its social implications, and this new spacefounded by social outcasts.

\section{Bibliographical References}

ASCHER François, 1995. Métapolis. O. Jacob Paris, $138 \mathrm{p}$

BALAN Hélène, 2017. Représentations et gestion de la marginalité sociale : le cas des biffins à Paris, Bulletin de l'association de géographesfrançais, Géographies N 94-3

BOURDIEU Pierre, 1982. Les rites comme actes d'institution. In: Actes de la recherche en sciences sociales. Vol. 43, juin. Rites et fétiches. pp. 58-63

CASTEL, R. (1994). La dynamique des processus de marginalisation:de la vulnérabilité à la désaffiliation,cahiers de recherche sociologique, 22, p11-27.

CHAMBOREDON, J.-C. (1980). Les usages urbains de l'espace rural;du moyen de production au lieu de récréation, revue française, 21-1, p97-119.

CUCHE Denys, 2009. «L'homme marginal » : une tradition conceptuelle à revisiter pour penser l'individu en diaspora, Revue européenne des migrations internationalesvol. $25-\mathrm{n}^{\circ} 3$ |

Anthropologie et migrations

GOFFMAN Erwin. (1975). Stigmate : Les usages sociaux des handicaps,minuit.

HOLAS Norbert, 1956. Fondements spirituels de la vie sociale senoufo, Journal des africanistes, $\mathbf{N}^{\circ} 26$, pp 9-31.

MATHIEU Nicole, 1997. «Pour une nouvelle approche spatiale de l'exclusion sociale », Srates n ${ }^{\circ}$. LADYSS. 10 $\mathrm{p}$

MAUGER Gérard, 2008. «Les communautés : une position sociale inédite », Nouveauxregards, $\mathrm{n}^{\circ}$ 40-41, avrilmai.

MONTAGNE Solange Villette, 2007. Les marginalités : du subi au choisi (The marginalities : from unvolontary to intentional). In: Bulletin de l'Association de géographes français, 84e année, №3 (septembre). Géographie et littérature / Marginalités spatiales et sociales. pp. 305-314

NOIREL Gérald, 2008, Introduction à la sociohistoire, Paris, la découverte, $128 \mathrm{p}$

PARE-KABORE Afsata, 2013. L'éducation traditionnelle et la vie communautaire en Afrique: repères et leçons d'expériences pour l'éducation au vivre-ensemble aujourd'hui, Revue des sciences de l'éducation de McGill, Vol 48, numéro 1, pp 15 - 33

PARK Robert, 1928. Human Migration and the Marginal Man, American Journal of Sociology,

37 (6), pp. 881-893.

RIOUX LILIANE, Les dimensions spatiale et culturelle de la marginalité. Une approche psychosociologique, sdl

ROCHEFORT René, 1986. «La marginalité de l'extérieur et de l'intérieur », in A. Vant (dir.), Marginalité sociale, marginalité spatiale, Paris, Editions du CNRS, pp. 26-34.

SAINT-GIRONS Franck, 2004. Marginalité et innovation culturelle dans les friches urbaines. Un enjeu dans l'aménagement du territoire. Thèse de Doctorat en Géographie et aménagement du territoire, Université de Pau et des pays de l'Adour, $440 \mathrm{p}$.

(http://www.larousse.fr/dictionnaires/francais, consulté le 17/09/2020) 